О. В. Лемешко ${ }^{1}$, А. С. Шаповалова ${ }^{1}$, О. С. Сременко ${ }^{1}$, М. О. Свдокименко ${ }^{1}$, А. М. Хайлан ${ }^{2}$

${ }^{1}$ Харківський національний університет радіоелектроніки, Харків, Україна

${ }^{2}$ Університет Ді-Кар, Насірія, Ірак

\title{
МАТЕМАТИЧНА МОДЕЛЬ ШВИДКОЇ ПЕРЕМАРШРУТИЗАЦІї З БАЛАНСУВАННЯМ НАВАНТАЖЕННЯ ТА ДИФЕРЕНЦЙОВАНОГО ОБМЕЖЕННЯ ТРАФІКА В МЕРЕЖАХ SD-WAN
}

\begin{abstract}
У роботі запропоновано математичну модель швидкої перемаршрутизації із забезпеченням балансування навантаження на принципах Traffic Engineering (ТЕ) та диференційованого обмеження трафіка в територіальнорозподілених програмно-конфігурованих мережах. Основу моделі складають умови реалізації багатошляхової маршрутизації сумісно з модифікованими умовами збереження потоку, які враховують пріоритетне обмеження трафіка на границі мережі у випадку її ймовірного перевантаження, викликаного, з одного боку, зростанням навантаження, а з іншого - реалізацією схем захисту елементів мережі та її пропускної здатності в ході швидкої перемаршрутизації. Перевагою запропонованого рішення також є формулювання задачі швидкої перемаршрутизації як оптимізаційної з критерієм, який орієнтує на мінімізацію, по-перше, верхнього порогу завантаженості каналів зв'язку, що відповідає вимогам концепції ТЕ, а, по-друге, зважених відносно пріоритету відмов в обслуговуванні потоків пакетів на границі мережі. Дослідження процесів швидкої перемаршрутизації з використанням запропонованої моделі на ряді числових прикладів підтвердило адекватність і ефективність отриманих на їі основі маршрутних рішень як щодо забезпечення їх відмовостійкості та балансування навантаження, так і щодо заснованого на пріоритетах обмеження трафіка.
\end{abstract}

Ключов і слова : SD-WAN, відмовостійкі мережі, управління трафіком, балансування навантаження, швидка перемаршрутизація, захист пропускної здатності.

\section{Вступ}

На сьогоднішній день впровадження територіально-розподілених програмно-конфігурованих мереж (Software-Defined Wide-Area Network, SD-WAN) $\epsilon$ перспективним технологічним рішенням, яке дозволяє поєднати мережні функції та послуги разом зі спрощенням інфраструктури та управління нею [13]. При цьому конфігурування мережі відокремлюється від базових мережних функцій, які надаються постачальниками мережних послуг, тим самим досягається більш ефективне використання пропускної здатності, а також забезпечується економія часу для розгортання та реконфігурації мережі під вимоги запитів користувачів. Різноманітні технологічні рішення, політики, інтелектуальні алгоритми маршрутизації, що можуть використовуватися в SDWAN, повинні допомагати адаптувати мережу щодо диференційованого обслуговування потоків [1-8].

У загальному випадку відповідно до вимог сучасних додатків користувачів можуть бути сформульовані наступні переваги SD-WAN:

- більш ефективне використання мережного ресурсу, при якому SD-WAN обиратиме найбільш придатну транспортну технологію 3 наявних для того чи іншого додатка, який формує потік даних для передавання мережею;

- краща керованість, яка дозволяє знизити витрати на адміністрування та управління мережею порівняно з традиційними мережами;

- високий рівень мережної безпеки, при якій шифрування потоків даних при їх передачі забезпечує захист при використанні будь-якої транспортної технології;

- гнучкість і масштабованість при перерозподілі пропускної здатності SD-WAN при диференційованому обслуговуванні потоків користувачів, що генеруються відповідними додатками, в тому числі критичними, яким має бути гарантовано обслуговування мережею.

При цьому слід відзначити, що при виборі того чи іншого технологічного рішення, орієнтованого на розгортання SD-WAN, необхідно забезпечити високий рівень його відмовостійкості до можливих збоїв в апаратному чи програмному забезпеченні мережного обладнання, перевантаження або порушення рівня інформаційної безпеки тощо. Як показав проведений аналіз, важливим технологічним інструментом підвищення надійності мережних рішень є відмовостійка маршрутизація, яка на транспортному рівні реалізована з використанням протоколів швидкої перемаршрутизації (FastReRouting, FRR) [9-15].

Швидка перемаршрутизація заснована на тому, що одночасно з основним шляхом, розраховується і множина резервних маршрутів, на які майже миттево $(40-50$ мс) перемикаються потоки пакетів при відмові основного шляху. Проте підтримка базових схем захисту елементів мережі (каналу / вузлу / шляху) та її пропускної здатності забезпечується за рахунок введення надмірності при використанні ресурс, що, в свою чергу, може негативно позначитись на продуктивності та рівні якості обслуговування (QualityofService, QoS) у цілому. Тому важливо, щоб, з одного боку, забезпечувалось ефективне (збалансоване) використання доступного мережного pecyрсу, наприклад, на принципах TrafficEngineering (TE) [13-22], а з іншого боку, в разі ймовірного перевантаження мережі, варто застосовувати функції обмеження навантаження на мережу, наприклад, інструментарій Traffic Policing (TP) [11, 12].

Слід зазначити, що забезпечення узгодженого вирішення завдань щодо відмовостійкої маршрутизації, балансування навантаження, обмеження трафіка, як правило, супроводжується ускладненням 
використовуваних математичних моделей та методів. Це в кінцевому випадку призводить як до підвищення рівня обчислювальної складності, так і до зниження масштабованості їх протокольної реалізаціï. Як показав аналіз [23], порядок FRR і TE визначається в процесі розв'язання оптимізаційних задач різного рівня складності.

\section{Основна частина}

1. Огляд рішень шодо швидкої перемаршрутизації 3 балансуванням навантаження в програмно-конфігурованих мережах Серед досліджень щодо відмовостійкості в SDN мережах можна виділити роботи [24-27]. Так, наприклад, в [24] запропоновано алгоритм локальної швидкої перемаршрутизації (Local Fast Reroute, LFR) з агрегацією потоків в програмно-конфігурованих мережах. В алгоритмі LFR в разі виявлення відмови каналу зв'язку всі потоки трафіка, уражені відмовою, агрегуються у так званий «великий» потік. Далі контролером SDN розгортається локальний резервний шлях для динамічної перемаршрутизації агрегованого потоку. Таким чином, алгоритм LFR зменшує кількість поточних операцій між контролером SDN і комутаційним обладнанням. Проведені числові результати довели, що LFR забезпечує швидке відновлення працездатності SDN.

Зростаюча складність сучасних мережних додатків та величезний попит на інтернет-ресурси вимагають від SDN здатності адаптуватися до вимог високого ступеню робастності та надійності. Як було сказано вище, в SDN надзвичайно актуальним $\epsilon$ саме завдання підвищення відмовостійкості та своєчасне оновлення інформації про стан мережі, яким присвячено дослідження [25]. У ньому визначені нові алгоритми, які спрямовані на покращення пошуку резервних шляхів у мережах великої розмірності при поодиноких відмовах каналів зв'язку з мінімальними часовими витратами на оновлення інформації про стан мережі. Нове рішення спрямоване на підвищення ефективності та зменшення операцій по обробці службової інформації під час відмов каналів зв'язку.

В роботі [27] запропоновано схему адаптивного динамічного обчислення множини шляхів 3 метою забезпечення ефективного управління мережними ресурсами для організації маршрутизації та розподілу ресурсів за умови централізованого управління програмно-конфігурованою мережею. Така система може забезпечити необхідну інфраструктуру для інтеграції збору даних та аналітики, оцінки продуктивності мережі при використанні різних алгоритмів оптимізації.

3 іншої сторони, як показано в роботах [28, 29], необхідність реалізації схеми захисту пропускної здатності мережі, особливо при реалізації багатошляхової стратегії маршрутизації, як правило, призводить до нелінійної постановки оптимізаційної задачі швидкої перемаршрутизації, що негативно впливає на обчислювальну складність кінцевих протокольних рішень. Крім того, в цих роботах не запропоновано варіанти дій, коли задача не має рішень, що може бути викликане, наприклад, відсутністю необхідного канального ресурсу для реалізації схем захисту пропускної здатності мережі, що має місце у випадку іiї перевантаження. Таким чином, актуальним науковим та прикладним завданням $\epsilon$ формалізація та забезпечення узгодженого вирішення таких складних мережних завдань, як швидка перемаршрутизація (FRR), балансування навантаження на принципах TE та обмеження трафіка (ТР) у випадку ймовірного перевантаження мережі. Це завдання пропонується розв'язати на підставі розробки відповідної математичної моделі, яка, грунтуючись на досвіді розробки та дослідження моделей QoS маршрутизації з підтримкою TP [28, 29], моделей і методів FRR і TE FRR [30-35], повинна відповідати таким ключовим вимогам:

- врахування особливостей структурної та функціональної побудови SD-WAN;

- підтримка багатошляхової стратегії маршрутизації в мережі;

- реалізація відомих схем забезпечення захисту елементів мережі, а також їх пропускної здатності;

- прийнятна обчислювальна складність та масштабованість кінцевих рішень, які підлягатимуть подальшій протокольній реалізації.

2. Потокова модель швидкої перемашрутизації з балансуванням навантаження та підтримкою диференційованого обмеження трафіка. Припустимо, що структура мережі зв'язку визначається графом $G=(R, E)$, де $R=\left\{R_{i} ; i=\overline{1, m}\right\}$ - це множина маршрутизаторів, $E=\left\{E_{i, j} ; i, j=\overline{1, m} ; i \neq j\right\} \quad-$ множина каналів зв'язку (К3). Позначимо через $R_{i}^{*}=\left\{R_{j}: \exists E_{j, i} \in E\right\}$ підмножину маршрутизаторів, які є суміжними для маршрутизатора $R_{i}$. Тоді кількість каналів зв'язку в мережі визначимо через $n=|E|$, де кожному з каналів зв'язку поставимо у відповідність його пропускну здатність $\varphi_{i, j}$.

У моделі $з$ кожним $k$-м потоком пов'язано ряд функціональних характеристик: $s_{k}$ - маршрутизаторвідправник; $d_{k}$ - маршрутизатор-одержувач пакетів; $\lambda^{k}$ - середня інтенсивність пакетів (пакетна швидкість) $k$-го потоку, що вимірюється в пакетах за секунду $(1 / \mathrm{c}) ; K$ - множина потоків пакетів, що передаються мережею $(k \in K)$.

Результатом розв'язання задачі швидкої перемашрутізації з балансуванням навантаження на основі Traffic Engineering $є$ обчислення двох типів маршрутних змінних $x_{i, j}^{k}$ та $\bar{x}_{i, j}^{k}$, які характеризують частку інтенсивності $k$-го потоку пакетів, які передаються у каналі зв'язку $E_{i, j} \in E$, що входить до основного або резервного шляху відповідно. У випадку, коли в SD-WAN використовується багатошляхова стратегія, на маршрутні змінні цих двох типів накладаються обмеження вигляду $[30,31]$ :

$$
0 \leq x_{i, j}^{k} \leq 1 \text { та } 0 \leq \bar{x}_{i, j}^{k} \leq 1 .
$$


На маршрутні змінні накладаються обмеження, які представлені умовами збереження потоку [28, 29]. Для основного шляху вони мають такий вигляд:

$$
\left\{\begin{array}{c}
\sum_{j: E_{i, j} \in E} x_{i, j}^{k}-\sum_{j: E_{j, i} \in E} x_{j, i}^{k}=0 \\
k \in K, R_{i} \neq s_{k}, d_{k} \\
\sum_{j: E_{i, j} \in E} x_{i, j}^{k}-\sum_{j: E_{j, i} \in E} x_{j, i}^{k}=1-\beta^{k} \\
k \in K, R_{i}=s_{k} \\
\sum_{j: E_{i, j} \in E} x_{i, j}^{k}-\sum_{j: E_{j, i} \in E} x_{j, i}^{k}=\beta^{k}-1 \\
k \in K, R_{i}=d_{k}
\end{array}\right.
$$

де $\beta^{k} \epsilon$ часткою інтенсивності $k$-го потоку, який при реалізації політики ТР отримує відмову в обслуговуванні (обмежується) на границі мережі при використанні основного шляху. На маршрутні змінні резервного шляху також накладаються умови, подібні до (2) [28]:

$$
\left\{\begin{array}{c}
\sum_{j: E_{i, j} \in E} \bar{x}_{i, j}^{k}-\sum_{j: E_{j, i} \in E} \bar{x}_{j, i}^{k}=0 \\
k \in K, R_{i} \neq s_{k}, d_{k} ; \\
\sum_{j: E_{i, j} \in E} \bar{x}_{i, j}^{k}-\sum_{j: E_{j, i} \in E} \bar{x}_{j, i}^{k}=1-\bar{\beta}^{k} ; \\
k \in K, R_{i}=s_{k} ; \\
\sum_{j: E_{i, j} \in E} \bar{x}_{i, j}^{k}-\sum_{j: E_{j, i} \in E} \bar{x}_{j, i}^{k}=\bar{\beta}^{k}-1 ; \\
k \in K, R_{i}=d_{k}
\end{array}\right.
$$

де $\bar{\beta}^{k} \epsilon$ часткою інтенсивності $k$-го потоку, який обмежується на границі мережі при використанні вже резервного шляху.

3. Умови захисту каналу, вузла та пропускної здатності при швидкій перемаршрутизації 3 балансуванням навантаження. У процесі швидкої багатошляховоїперемаршрутизації 3 балансуванням навантаження при реалізації схеми захисту каналу $E_{i, j} \in E$ має місце таке обмеження [32]

$$
0 \leq \bar{x}_{i, j}^{k} \leq \delta_{i, j}^{k}
$$

де $\delta_{i, j}^{k}=\left\{\begin{array}{l}0, \text { при захисті канала зв'язку } E_{i, j} ; \\ 1, \text { в іншому випадку. }\end{array}\right.$

Виконання лінійних умов (4) і (5) гарантує, що канал $E_{i, j} \in E$, який захищається, при багатошляховій маршрутизації не буде використовуватисярезервним маршрутом.

У свою чергу, при реалізації схеми захисту вузла $R_{i} \in R$ умови (4) і (5) узагальнюються на випадок захисту вже множини каналів зв'язку, інцидентних вузлу, який захищається [32]. Тоді в разі використання багатошляхової стратегії повинні виконуватися такі обмеження:

$$
0 \leq \bar{x}_{i, j}^{k} \leq \delta_{i, j}^{k}, R_{j} \in R_{i}^{*}, j=\overline{1, m},
$$

де значення $\delta_{i, j}^{k}$ визначаються відповідно до (5).

Слід зазначити, що виконання зазначених вище умов (5) і (6) гарантує захист вузла $R_{i} \in R$, забороняючи використання резервним маршрутом усіх каналів, які виходять 3 даного вузла. Більш того, відповідно до умов (4), так як захисту підлягають лише транзитні маршрутизатори, заборона на використання вихідних каналів зв'язку запобігає включенню до резервного шляху і вхідних каналів. Так реалізується захист конкретного вузла $R_{i}$ мережі в цілому.

Умови захисту пропускної здатності SD-WAN фактично відповідають за своїм фізичним змістом умовам запобігання перевантаження каналів зв'язку при реалізації швидкої перемаршрутизації:

$$
\sum_{k \in K} \lambda^{k} \cdot \max \left[x_{i, j}^{k}, \bar{x}_{i, j}^{k}\right] \leq \varphi_{i, j}, E_{i, j} \in E .
$$

Нелінійні умови (7) охоплюють самий загальний випадок, коли перемикатися на резервні маршрути можуть не всі потоки одночасно, а лише деякі 3 них, так як для різних потоків можуть резервуватись різні елементи (вузли або канали) мережі.

Як показано в роботах $[35,36]$, в умовах реалізації багатошляхової маршрутизації з метою запобігання перевантаження та забезпечення балансування навантаження в мережі на принципах ТЕ нелінійні умови (7) заміняються лінійними аналогами:

$$
\begin{gathered}
\sum_{k \in K} \lambda^{k} \cdot u_{i, j}^{k} \leq \alpha \cdot \varphi_{i, j}, E_{i, j} \in E \\
x_{i, j}^{k} \leq u_{i, j}^{k} \text { та } \bar{x}_{i, j}^{k} \leq u_{i, j}^{k}
\end{gathered}
$$

3 деяким розширенням множини керуючих змінних: по-перше, в (8) та (9) вводяться змінні $u_{i, j}^{k}$, кожна 3 яких характеризує верхній поріг значень відповідних маршрутних змінних $x_{i, j}^{k}$ та $\bar{x}_{i, j}^{k}(9)$ для основних та резервних шляхів та відповідає обмеженням

$$
0 \leq u_{i, j}^{k} \leq 1
$$

по-друге, вводиться керуюча змінна $\alpha$, яка кількісно визначає верхній поріг завантаженості каналів зв'язку мережі, відповідаючи наступним умовам

$$
0 \leq \alpha \leq \alpha_{T H},
$$

де $\alpha_{T H}-$ граничне значення верхнього порогу завантаженості каналів зв'язку мережі, величина якої попередньо задається на основі аналізу вимог щодо рівня якості обслуговування в мережі.

Це обумовлено тим, що всі основні показники якості обслуговування - продуктивність мережі, середня міжкінцева затримка та ймовірність втрат пакетів $є$ функцією від цього параметра. Чим вище рівень QoS-вимог в мережі, тим нижчим обирається значення порогу $\alpha_{T H}$. 
Введення умов (11) є новизною запропонованого підходу в порівнянні з моделями, запропонованими в роботах $[34,35]$.

При цьому, збереження лінійності моделі (1)-(11) і орієнтація на забезпечення заданого рівня QoS можна віднести до основних переваг запропонованого рішення.

Критерієм оптимальності рішення завдання швидкої перемашрутизації з балансуванням навантаження $з$ підтримкою обмеження трафіка буде виступати мінімум наступної цільової функції:

$$
J=\sum_{k \in K} w_{k} \cdot \beta^{k}+\sum_{k \in K} \bar{w}_{k} \cdot \bar{\beta}^{k}+c \cdot \alpha \rightarrow \min ,
$$

де вагові коефіцієнти повинні відповідати таким умовам

$$
w_{k}>\bar{w}_{k}>w_{p}>\bar{w}_{p}>\ldots>c
$$

де пріоритет пакетів $k$-го потоку $\left(P R^{k}\right)$ перевищує пріоритет пакетів $p$-го потоку $\left(P R^{p}\right)$.

Наприклад, в IP-мережі у разі використання трьох біт у заголовку пакета для кодування пріоритету його значення знаходиться в діапазоні від 0 до 7, а при використанні політик DSCP (Differentiated Services Code Point) пріоритети змінюються від 0 до 63. Тоді, згідно з (13) пропонується використовувати в критерії (12) такі значення вагових коефіцієнтів:

$$
w_{k}=P R^{k}+1, \bar{w}_{k}=P R^{k}+0,5, c=0,25 .
$$

Критерій оптимальності (12) фокусується на мінімізації умовних витрат, пов'язаних 3 погодженим вирішенням завдань FRR, TE та TP. У цьому випадку перший член визначає умовну вартість відмов для підтримки потоків, що передаються за допомогою основних шляхів; другий - умовну вартість відмов у обслуговуванні (обмеженні) потоків, що передаються через резервні шляхи; третій член в (12) описує зважений верхній поріг завантаженості каналів зв'язку мережі.

Введена ієрархія значень вагових коефіцієнтів (14) продиктована тим, що на першому місці за важливістю $є$ рішення задачі обмеження трафіка. При цьому, чим вище пріоритет пакетів потоку, тим вагові коефіцієнти повинні бути більшими.

Варто зазначити, що для одного й того ж самого потоку умовна вартість обмеження трафіка при використанні основного шляху повинна бути вищою за подібну вартість при використанні цим же потоком резервного маршруту.

4. Дослідження запропонованої моделі швидкої перемаршрутизації в мережі SD-WAN. Проведено аналіз запропонованої моделі швидкої перемаршрутизації з балансуванням навантаження на різних мережних конфігураціях для різної кількості потоків та їх характеристик.

Особливості моделі продемонструємо на розрахункових прикладах. Структура досліджуваної мережі показана на рис. 1, а в розривах каналів зв’язку мережі вказані їх пропускні здатності. При- пустимо, що існує необхідність у вирішенні задачі швидкої перемашрутизації із забезпеченням захисту пропускної здатності мережі та каналу Е11,12 для двох потоків:

- перший потік передається від вузла $R_{1}$ до вузла $R_{16}$ зі змінюваною інтенсивністю $\lambda^{1}=10 \div 11001 /$ с та пріоритетом $P R^{1}=4$;

- другий потік передається від вузла $R_{5}$ до вузла $R_{12}$ зі змінюваною інтенсивністю $\lambda^{2}=10 \div 11001 /$ с та пріоритетом $P R^{2}=1$.

Таким чином, другий потік має нижчий пріоритет, ніж перший.

Передбачається, що граничне значення верхнього порогу завантаженості каналів зв'язку мережі обрано таким: $\alpha_{T H}=0,75$.

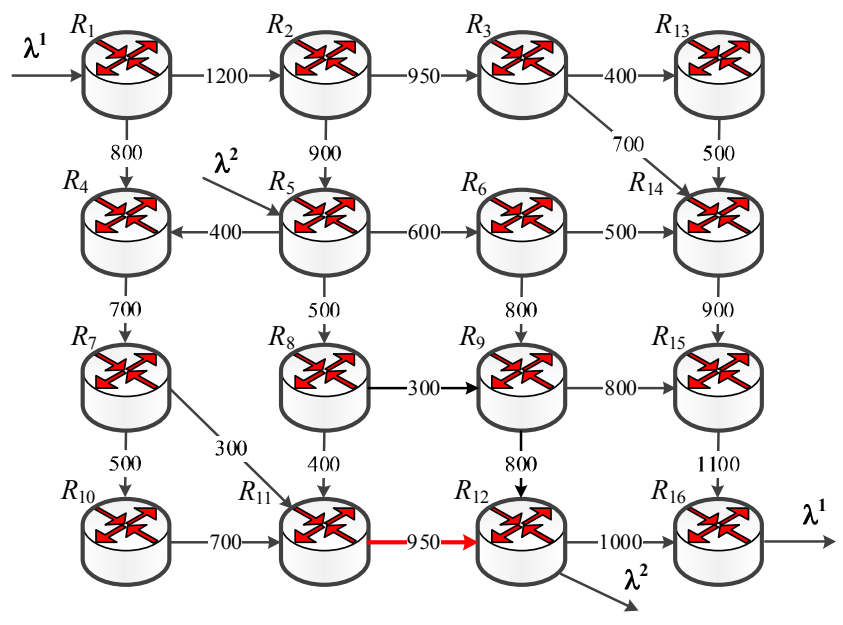

Рис. 1. Структура досліджуваної мережі

Як показали результати досліджень, що представлені на рис. 2, зі зростанням навантаження на мережу, верхній поріг завантаженості каналів зв'язку мережі також поступово зростав. Відсутність різких коливань у значеннях $\alpha$ (рис. 2 , а) позитивно впливає на якість обслуговування в мережі в цілому. При цьому при невисокій завантаженості мережі, коли $\lambda^{1} \leq 9001 / \mathrm{c}$ та $\lambda^{2} \leq 8301 / \mathrm{c}$, виконання умови (11) при $0 \leq \alpha \leq \alpha_{T H}$ не викликало обмеження інтенсивності потоків на границі мережі, тобто $\beta^{1}=\bar{\beta}^{1}=\beta^{2}=\bar{\beta}^{2}=0$ (рис. 2 ).

Проте, при надмірному навантаженні на мережу виконання умови (11) забезпечувалось у спосіб, коли $\alpha=\alpha_{T H}$ (рис. 2 а) за рахунок обмеження інтенсивностей потоків, які протікали як за основними, так і за резервними шляхами. Як видно 3 рис. 2, обмеження трафіка відбувалось за двома основними принципами:

- обмеження, перш за все, стосувались того потоку, який є джерелом перевантаження за умовою (11);

- якщо перевантаження створювали декілька потоків, то обмеження, перш за все, стосувались потоку з меншим пріоритетом відповідно до умов (13) та (14). 

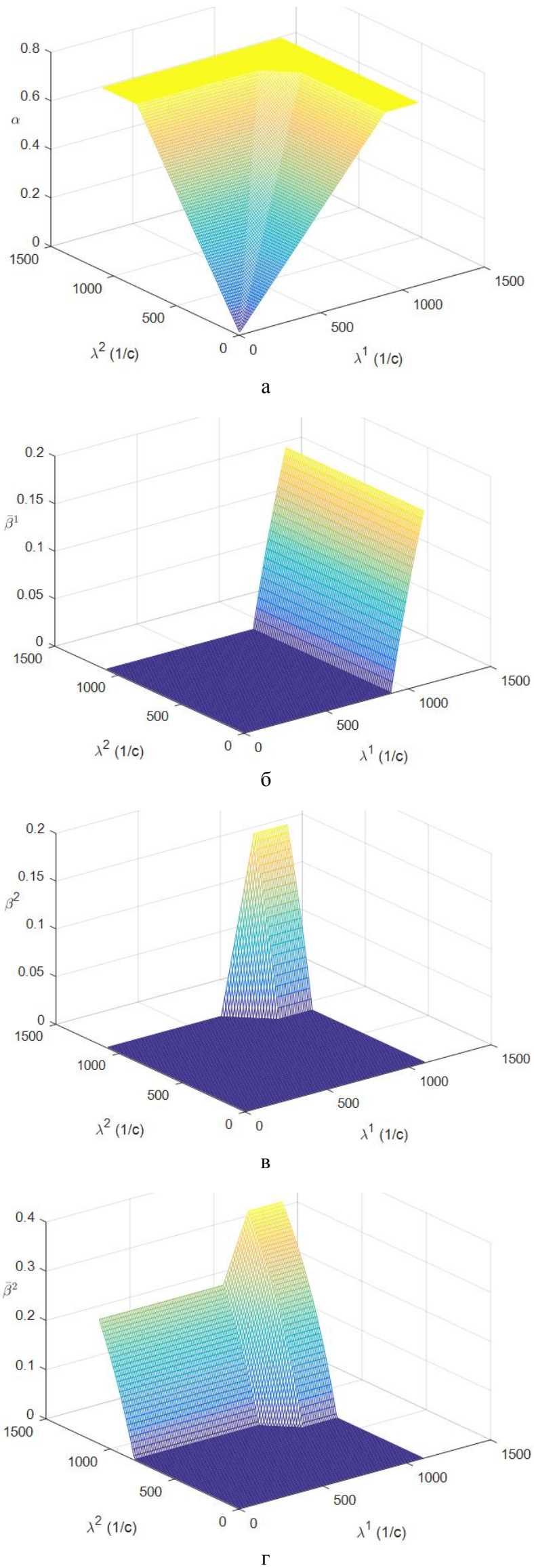

Рис. 2. Результати дослідження для $\alpha_{T H}=0,75$

Підтвердженням цих принципів $є$ те, що при зазначених вихідних даних перший (високопріори- тетний) потік пакетів у ході використання основного маршруту за своєю інтенсивністю не обмежувався, тобто $\beta^{1}=0$.

Раніше за всіх та з більшою інтенсивністю обмежувався другий (низькопріоритетний) потік при використанні ним резервного шляху (рис. 2, г). Дещо пізніше і з меншою інтенсивністю обмежувався другий потік при використанні ним основного шляху (рис. 2, в). Перший потік, який мав високий пріоритет, обмежувався лише у випадку створення ним перевантаження каналів, що входили до резервного шляху (рис. 2, б).

Для наочності далі розглянемо більш детально отримані результати (рис. 2), коли $\lambda^{1}=9501 / \mathrm{c}$ та $\lambda^{2}=10001 / \mathrm{c}$.

У табл. 1, наведено результати розв'язання задачі TE-FRR-TP для двох описаних потоків. Розрахунок коефіцієнту використання $\alpha_{i, j}$ для кожного каналу мережі можна провести, як зазначено в [35], за формулою:

$$
\alpha_{i, j}=\frac{\sum_{k \in K} u_{i, j}^{k} \lambda^{k}}{\varphi_{i, j}} .
$$

В умовах перевантаження мережі для забезпечення виконання умови (11) були отримані такі результати розрахунків:

- перший потік, який мав високий пріоритет $\left(P R^{1}=4\right)$, при використанні резервного шляху буде отримувати відмову обслуговування на границі мережі 3 інтенсивністю 50 1/c, що відповідає $\bar{\beta}^{1}=0,0526$;

- другий потік, який мав низький пріоритет $\left(P R^{2}=1\right)$, при використанні основного шляху буде отримувати відмову обслуговування на границі мережі 3 інтенсивністю 100 1/с, яка відповідає $\beta^{2}=0,1$;

- другий потік, який мав низький пріоритет $\left(P R^{2}=1\right)$, при використанні резервного шляху отримує відмову обслуговування на границі мережі 3 інтенсивністю у $3251 / \mathrm{c}$, яка відповідає $\bar{\beta}^{2}=0,325$.

Як показали результати дослідження, модель дозволяє $з$ одного боку забезпечити диференційоване обмеження трафіка на основі пріоритетів, а 3 іншого - можливість обмеження саме того потоку, який є джерелом перевантажень.

Це проявляється в тому, що при перевантаженні спільно використовуваних розглянутими двома потоками каналів (E5,4, E5,6, E5,8, Е7,11 та Е8,9) обмежувався за своєю інтенсивністю саме другий (менш пріоритетний) потік (табл. 1).

3 огляду на ймовірне порушення умови (11), викликане перевантаженням невикористовуваних другим потоком каналів $\mathrm{E}_{1,2}$ та $\mathrm{E}_{14,15}$ (табл. 1), обмежувався і перший (високопріоритетний) потік, як це показано на рис. 2 , б. 
Таблиця 1 - Порядок багатошляхової маршрутизації двох потоків із застосуванням запропонованої моделі швидкої перемаршрутизації з балансуванням навантаження з підтримкою обмеження трафіка (захист каналу Е11,12)

\begin{tabular}{|c|c|c|c|c|c|}
\hline \multirow{2}{*}{$\begin{array}{c}\text { Канал } \\
\text { зв'язку }\end{array}$} & \multicolumn{2}{|c|}{$\begin{array}{c}\text { Інтенсивність першого потоку } \\
\text { в каналах зв'язку }\end{array}$} & \multicolumn{2}{|c|}{$\begin{array}{c}\text { Інтенсивність другого потоку } \\
\text { в каналах зв'язку }\end{array}$} & \multirow{2}{*}{$\alpha_{i, j}$} \\
\hline & Основний шлях & Резервний шлях & Основний шлях & Резервний шлях & \\
\hline$E_{1,2}$ & 788,17 & 900 & $\mathbf{0}$ & $\mathbf{0}$ & $\mathbf{0 , 7 5}$ \\
\hline$E_{2,3}$ & 592,87 & 675 & 0 & 0 & 0,74 \\
\hline$E_{1,4}$ & 161,83 & 0 & 0 & 0 & 0,68 \\
\hline$E_{2,5}$ & 195,30 & 225 & 0 & 0 & 0,69 \\
\hline$E_{3,6}$ & 406,66 & 449,18 & 0 & 0 & 0,73 \\
\hline$E_{5,4}$ & 0 & 0 & 300 & 225 & 0,75 \\
\hline$E_{5,6}$ & 113,98 & 129,87 & 320,13 & 320,13 & 0,75 \\
\hline$E_{4,7}$ & 161,83 & 0 & 300 & 225 & 0,73 \\
\hline$E_{5,8}$ & 81,32 & 95,13 & 279,87 & 129,87 & 0,75 \\
\hline$E_{6,9}$ & 86,95 & 129,87 & 320,13 & 320,13 & 0,72 \\
\hline$E_{7,8}$ & 0 & 0 & 189,75 & 225 & 0,75 \\
\hline$E_{8,9}$ & 52,59 & 95,13 & 96,84 & 129,87 & 0,75 \\
\hline$E_{7,10}$ & 161,83 & 0 & 110,25 & 0 & 0,71 \\
\hline$E_{8,11}$ & 28,73 & 0 & 183,03 & 0 & 0,71 \\
\hline$E_{9,12}$ & 66,14 & 126,71 & 416,97 & 450 & 0,74 \\
\hline$E_{10,11}$ & 161,83 & 0 & 110,25 & 0 & 0,69 \\
\hline$E_{11,12}$ & 190,56 & 0 & 293,28 & 0 & 0,71 \\
\hline$E_{3,13}$ & 186,21 & 225,82 & 0 & 0 & 0,72 \\
\hline$E_{13,14}$ & 186,21 & 225,82 & 0 & 0 & 0,71 \\
\hline$E_{6,14}$ & 27,03 & 0 & 0 & 0 & 0,66 \\
\hline$E_{14,15}$ & 619,90 & 675 & 0 & $\mathbf{0}$ & 0,75 \\
\hline$E_{9,15}$ & 73,40 & 98,29 & 0 & 0 & 0,67 \\
\hline$E_{15,16}$ & 693,30 & 773,29 & 0 & 0 & 0,74 \\
\hline$E_{12,16}$ & 256,70 & 126,71 & 0 & 0 & 0,69 \\
\hline
\end{tabular}

Далі розглянемо випадок, коли граничне значення верхнього порогу завантаженості каналів зв'язку мережі буде мати нижче значення $\alpha_{T H}=0,65$. Відзначимо, що зниження порогового значення $\alpha_{T H}$ може бути викликане, наприклад,

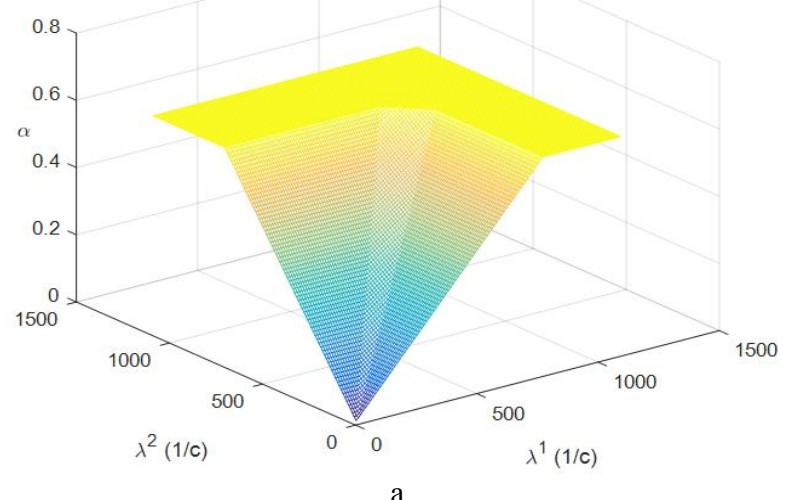

a

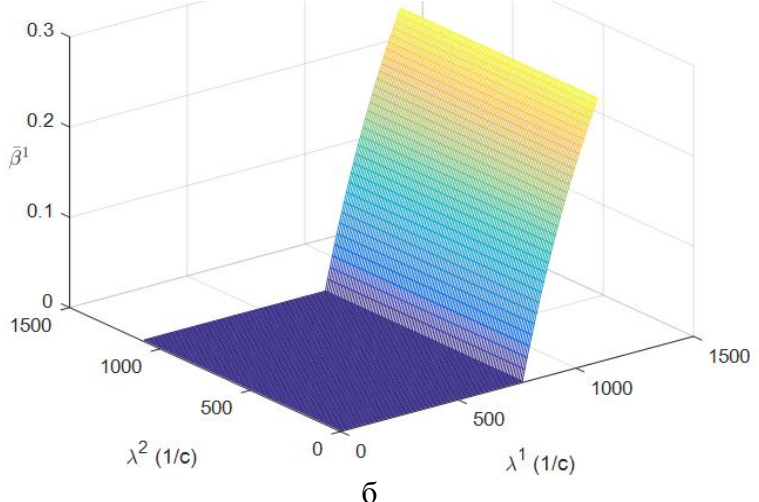

підвищенням вимог до рівня якості обслуговування.

Результати розрахунків представлені на рис. 3 при вихідних даних для двох потоків, які відповідали попередньому прикладу.
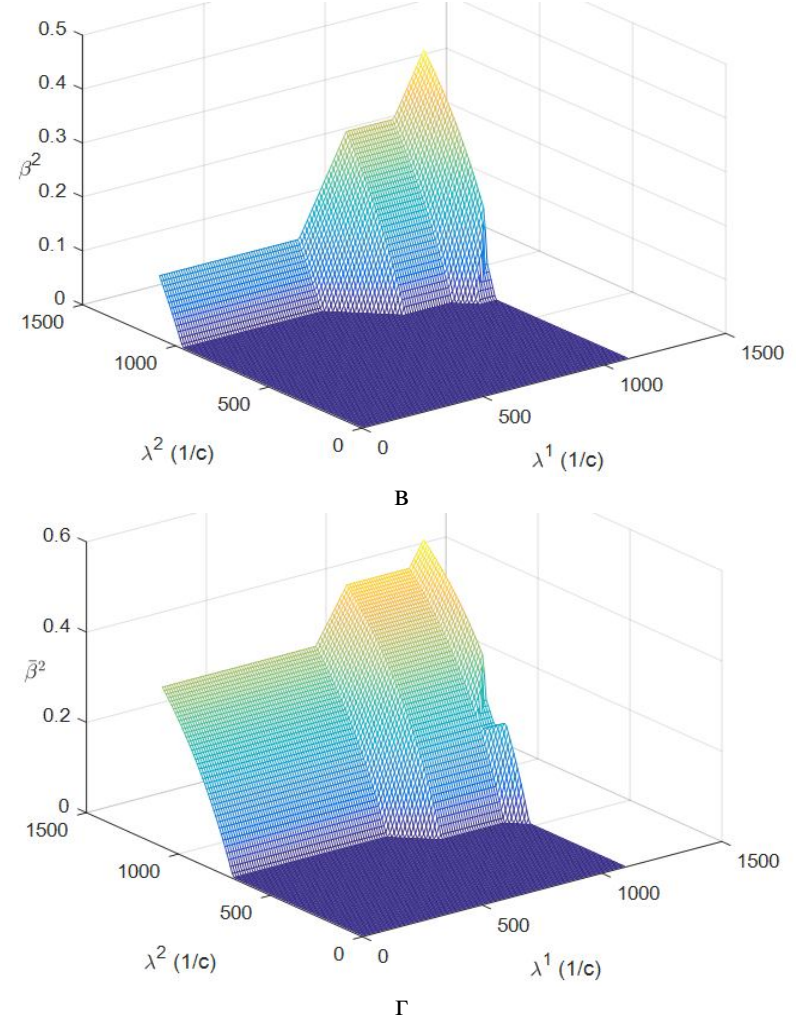

Рис. 3. Результати дослідження для $\alpha_{T H}=0,65$ 
Отримані результати дослідження (рис. 3) підтвердили попередній висновок, що зростання навантаження на мережу призводить до поступового збільшення верхнього порогу завантаженості каналів зв'язку (рис. 3, а).

Як і раніше, при невисокій завантаженості мережі $\left(0 \leq \alpha<\alpha_{T H}\right)$, обмеження інтенсивності потоків на границі мережі було відсутне, тобто $\beta^{1}=\bar{\beta}^{1}=\beta^{2}=\bar{\beta}^{2}=0$.

Але завдяки тому, що граничне значення $\alpha_{T H}=0,65$ стало більш жорстким, обмеження трафіка починалось при дещо менших значеннях інтенсивностей вхідних потоків: $\lambda^{1}>7801 / \mathrm{c}$, $\lambda^{2}>7201 / \mathrm{c}$ (рис. 3, a).

При подальшому збільшенні навантаження на мережу умови (11) виконувались лише при $\alpha=\alpha_{T H}$ (рис. 3 , а) за рахунок обмеження інтенсивностей потоків, які протікали за основними і резервними шляхами. При цьому, як і в попередньому прикладі, обмеження трафіка (Traffic Policing) відбувалось диференційовано згідно до пріоритетів потоків (13) та залежно від того, який саме потік пакетів провокував перевантаження мережі та невиконання умови (11).

Як і в попередньому випадку (рис. 2), при зазначених вихідних даних перший потік пакетів, який мав високий пріоритет, при використанні основного маршруту за своєю інтенсивністю не обмежувався $\left(\beta^{1}=0\right)$. 3 більшою інтенсивністю обмежувався другий потік, який мав низький пріоритет та передавався за резервним шляхом (рис. 3 , г). Тоді як при використанні основного шляху другий потік обмежувався менш інтенсивно (рис. 3, в). Перший потік з високим пріоритетом обмежувався лише при перевантаженні каналів, що входили до резервного шляху (рис. 3, б).

\section{Висновки}

1. Рішення з підвищення відмовостійкості SDWAN на основі реалізації швидкої перемаршрутизації базуються на резервуванні іï елементів та пропускної здатності. Тобто введення ресурсної надлишковості є своєрідною платнею за підвищення надійності мережних рішень. Проте резервування мережного ресурсу в ході реалізації тієї чи іншої схеми захисту завжди негативно впливає на продуктивність мережі та рівень якості обслуговування в цілому. Тобто з підвищенням навантаження на мережу реалізація схем захисту елементів мережі, а особливо її пропускної здатності в ході швидкої перемаршрутизації може призвести до нестачі мережного, перш за все, канального ресурсу та подальшого перевантаження.

2. Встановлено, що ефективним проактивним засобом боротьби 3 перевантаженням мережі є забезпечення збалансованого використання доступного мережного ресурсу на принципах концепції Traffic Engineering. Дієвим реактивним методом боротьби з перевантаженням $€$ профілювання трафі- ка, а зокрема обмеження його інтенсивності на границі мережі відповідно до пріоритету обслуговування пакетів. Тому для практики дуже затребуваними $\epsilon$ теоретичні рішення щодо забезпечення погодженого розв'язання мережних задач зі швидкої перемаршрутизації на принципах ТЕ та диференційованого обмеження трафіка.

3. У зв'язку з цим у роботі запропоновано математичну модель швидкої перемаршрутизації 3 балансуванням навантаження на принципах ТЕ та диференційованим обмеженням трафіка в SD-WAN (1)-(15). Основу моделі складають умови реалізації багатошляхової маршрутизації (1), модифіковані умови збереження потоку (2), (3), які враховують пріоритетне обмеження трафіка на границі мережі у випадку іiі ймовірного перевантаження, викликаного, 3 одного боку, зростанням навантаження, а 3 іншого - реалізацією схем захисту елементів мережі та іiї пропускної здатності в ході швидкої перемаршрутизації. У роботі адаптовані під нові вимоги умови забезпечення захисту (резервування) вузла, каналу (4)-(6) та пропускної здатності мережі (8)-(10).

4. Перевагою запропонованого рішення також $\epsilon$ формулювання задачі TE-FRR-TP як оптимізаційного завдання 3 критерієм оптимальності (12), який орієнтує на мінімізацію, по-перше, верхнього динамічно керованого порогу завантаженості каналів зв'язку $(\alpha)$, що відповідає вимогам концепції ТЕ, а, по-друге, відмов в обслуговуванні на границі мережі, зважених відносно пріоритету та інтенсивності потоків. В ході пріоритезації потоків, які передаються за основним або резервним шляхом (мультишляхом), необхідно забезпечити виконання умови (13).

5. Як обмеження при оптимізації виступатимуть умови реалізації багатошляхової маршрутизації (1), збереження потоку (2), (3), а також захисту каналу (4), вузла (6) або пропускної здатності мережі (8)-(10). Лінійність сформульованої оптимізаційної задачі забезпечувалась шляхом деякого розширення числа керуючих змінних (8)-(10), які визначають верхній поріг для маршрутних змінних основного та резервного шляхів. Використання запропонованого підходу дозволяє знизити обчислювальну складність розрахунку маршрутних змінних, що відповідають за формування основного та резервного шляхів.

Крім того, забезпечується збалансована завантаженість каналів зв'язку мережі, що відповідає вимогам концепції Traffic Engineering.

6. Дослідження процесів швидкої перемаршрутизації з використанням запропонованої моделі (1)(15) на ряді числових прикладів (рис. 1 - рис. 3 ) підтвердило адекватність і ефективність отриманих на іiі основі маршрутних рішень як щодо забезпечення їх відмовостійкості та балансування навантаження, так і щодо обмеження трафіка. При цьому в ході обмеження трафіка реалізувались два важливі принципи: по-перше, обмеження, перш за все, стосувались того потоку, який є джерелом перевантаження за умовою (11); по-друге, якщо перевантаження створювали декілька потоків, то обмеження, 
перш за все, стосувались потоку з меншим пріоритетом відповідно до умов (13).

7. Запропонована модель може стати основою алгоритмічно-програмного забезпечення контроле- рів SD-WAN, які відповідають за централізований розрахунок множин основних та резервних шляхів при реалізації швидкої перемаршрутизації потоків користувачів.

\section{СПИСОК ЛІТЕРАТУРИ}

1. Blokdyk, G.: Software-Defined WAN SD-WAN A Clear and Concise Reference. 5STARCooks (2018)

2. Blokdyk, G.: SD-WAN A Complete Guide. 5STARCooks (2018)

3. Naggi, R., Srivastava, R.: SD-WAN The Networking Blueprint for Modern Businesses. Amazon Digital Services LLC (2018)

4. White, M.B.: Computer Networking: The Complete Guide to Understanding Wireless Technology, Network Security, Computer Architecture and Communications Systems (Including Cisco, CCNA and CCENT). CreateSpace Independent Publishing Platform (2018)

5. Monge, A.S., Szarkowicz, K.G.: MPLS in the SDN Era: Interoperable Scenarios to Make Networks Scale to New Services. O'Reilly Media (2016)

6. Zaitsev, D.A., Shmeleva, T.R., Retschitzegger, W., Pröll, B.: Security of grid structures under disguised traffic attacks. Cluster Computing. 19(3), 1183-1200 (2016). https://doi.org/10.1007/s10586-016-0582-9

7. Smelyakov, K., Dmitry, P., Vitalii, M., Anastasiya, C. Investigation of network infrastructure control parameters for effective intellectual analysis. In: 2018 14th International Conference on Advanced Trends in Radioelecrtronics, Telecommunications and Computer Engineering (TCSET) Proceedings. pp. 983-986. IEEE (2018). https://doi.org/10.1109/tcset.2018.8336359

8. Ruban, I.V., Churyumov, G.I., Tokarev, V.V., Tkachov, V.M.: Provision of Survivability of Reconfigurable Mobile System on Exposure to High-Power Electromagnetic Radiation. Selected Papers of the XVII International Scientific and Practical Conference on Information Technologies and Security (ITS 2017). CEUR Workshop Processing. 105-111 (2017)

9. Papán, J., Segeč, P., Palúch, P., Mikuš, L., Moravčík, M.: The Survey of Current IPFRR Mechanisms. In: 2015 Federated Conference on Software Development and Object Technologies (SDOT 2015). Advances in Intelligent Systems and Computing, 511, 229-240 (2015). https://doi.org/10.1007/978-3-319-46535-7_18.

10. Al-shawi, M., Laurent, A.: Designing for Cisco Network Service Architectures (ARCH) Foundation Learning Guide: CCDP ARCH 300-320. 4th edition, Cisco Press (2017)

11. Misner, I., Hilliard, B.: Networking Like a Pro: Turning Contacts into Connections. Second edition, Entrepreneur Press (2017)

12. Ross, K., Kurose, J.: Computer Networking: A Top-Down Approach, Global Edition. 7th edition, Pearson Higher Education (2016)

13. Golani, K., Goswami, K., Bhatt, K., Park, Y.: Fault Tolerant Traffic Engineering in Software-defined WAN. In: 2018 IEEE Symposium on Computers and Communications (ISCC) Proceedings, pp. 01205-01210. IEEE (2018). https://doi.org/10.1109/ISCC.2018.8538606

14. Tomovic, S., Radusinovic, I.: A new traffic engineering approach for QoS provisioning and failure recovery in SDN-based ISP networks. In: 2018 23rd International Scientific-Professional Conference on Information Technology (IT) Proceedings, pp. 1-4. IEEE (2018). https://doi.org/10.1109/SPIT.2018.8350854

15. Lin, S.C., Wang, P., Luo, M.: Control traffic balancing in software defined networks. Computer Networks, 106, 260-271 (2016)

16. Wang, Y., Wang, Z.: Explicit routing algorithms for Internet Traffic Engineering. In: Eight International Conference on Computer Communications and Networks (Cat. No.99EX370) Proceedings, pp. 582-588. IEEE (1999). https://doi.org/10.1109/ICCCN.1999.805577

17. Seok, Y., Lee, Y., Kim, C., Choi, Y. Dynamic Constrained Multipath Routing for MPLS Networks. In: Tenth International Conference on Computer Communications and Networks (Cat. No.01EX495) Proceedings, pp. 348-353. IEEE (2001). https://doi.org/10.1109/ICCCN.2001.956289.

18. Mendiola, A., Astorga, J., Jacob, E., Higuero, M.: A survey on the contributions of Software-Defined Networking to Traffic $\begin{array}{lllllll}\text { Engineering. IEEE Communications Surveys \& } & \text { Tutorials. } & 19(2), & 918-953 & \text { (2017) }\end{array}$ https://doi.org/10.1109/COMST.2016.2633579

19. Prabhavat, S., Nishiyama, H., Ansari, N., Kato, N.: On load distribution over multipath networks. IEEE Communications Surveys \& Tutorials. 14(3), 662-680 (2012) https://doi.org/10.1109/SURV.2011.082511.00013

20. Koryachko, V.P., Perepelkin, D.A., Byshov, V.S.: Development and research of improved model of multipath adaptive routing in computer networks with load balancing. Aut. Control Comp. Sci. 51(1), 63-73 (2017) https://doi.org/10.3103/S0146411617010047

21. Koryachko, V.P., Perepelkin, D.A., Byshov, V.S.: Enhanced Dynamic Load Balancing Algorithm in Computer Networks with Quality of Services. Aut. Control Comp. Sci. 52(4), 268-282 (2018) https://doi.org/10.3103/S0146411618040077

22. Perepelkin, D., Byshov, V.: Visual design environment of dynamic load balancing in software defined networks. In: 2017 27th International Conference Radioelektronika (RADIOELEKTRONIKA) Proceedings, pp. 1-4. IEEE (2017). https://doi.org/10.1109/RADIOELEK.2017.7936643

23. Wang, N., Ho, K., Pavlou, G., Howarth, M.: An overview of routing optimization for internet traffic engineering. IEEE Communications Surveys \& Tutorials. 10(1), 36-56 (2008) https://doi.org/10.1109/COMST.2008.4483669

24. Zhang, X., Cheng, Z., Lin, R., He, L., Yu, S., Luo, H.: Local Fast Reroute With Flow Aggregation in Software Defined Networks. IEEE Communications Letters. 21(4), 785-788 (2017). https://doi.org/10.1109/LCOMM.2016.2638430

25. Malik, A., Aziz, B., Adda, M., Ke, C.H.: Optimisation methods for fast restoration of software-defined networks. IEEE Access 5, 16111-16123 (2017). https://doi.org/10.1109/ACCESS.2017.2736949.

26. Rzym, G., Wajda, K., Chołda, P.: SDN-based WAN optimization: PCE implementation in multi-domain MPLS networks supported by BGP-LS. Image Processing \& Communications. 22(1), 35-48 (2017). https://doi.org/10.1515/ipc-2017-0004 
27. Luo, M., Zeng, Y., Li, J., Chou, W.: An adaptive multi-path computation framework for centrally controlled networks. Computer Networks, 83, 30-44 (2015). https://doi.org/10.1016/j.comnet.2015.02.004

28. Lemeshko, O.V., Garkusha, S.V., Yeremenko, O.S., Hailan, A.M.: Policy-based QoS Management Model for Multiservice Networks. In: 2015 International Siberian Conference on Control and Communications (SIBCON) Proceedings, pp. 1-4. IEEE (2015). https://doi.org/10.1109/SIBCON.2015.7147124

29. Lemeshko, A.V., Evseeva, O.Y., Garkusha, S.V.: Research on tensor model of multipath routing in telecommunication network with support of service quality by greate number of indices. Telecommun. Radio Eng. 73(15), 1339-1360 (2014) https://doi.org/10.1615/TelecomRadEng.v73.i15.30

30. Lemeshko, O., Arous, K., Tariki, N.: Effective solution for scalability and productivity improvement in fault-tolerant routing. In: 2015 Second International Scientific-Practical Conference Problems of Infocommunications Science and Technology (PIC S\&T) Proceedings, pp. 76-78. IEEE (2015). https://doi.org/10.1109/INFOCOMMST.2015.7357274

31. Lemeshko, O.V., Yeremenko, O.S.: Dynamics analysis of multipath QoS-routing tensor model with support of different flows classes. In: 2016 International Conference on Smart Systems and Technologies (SST) Proceedings, pp. 225-230. IEEE (2016). https://doi.org/10.1109/SST.2016.7765664

32. Yeremenko, O.S., Lemeshko, O.V., Tariki, N.: Fast ReRoute Scalable Solution with Protection Schemes of Network Elements. In: 2017 IEEE First Ukraine Conference on ELECTRICAL AND COMPUTER ENGINEERING (UKRCON) Proceedings, pp. 783-788. IEEE (2017). https://doi.org/10.1109/UKRCON.2017.8100353

33. Lemeshko, O., Yeremenko, O., Hailan, A.M.: Two-level Method of Fast ReRouting in Software-Defined Networks. In: 2017 4th International Scientific-Practical Conference Problems of Infocommunications. Science and Technology (PIC S\&T) Proceedings, pp. 376-379. IEEE (2017). https://doi.org/10.1109/INFOCOMMST.2017.8246420

34. Lemeshko, O., Yeremenko, O.: Enhanced method of fast re-routing with load balancing in software-defined networks. Journal of Electrical Engineering, 68(6), 444-454 (2017). https://doi.org/10.1515/jee-2017-0079

35. Lemeshko, O., Yeremenko, O.: Linear optimization model of MPLS Traffic Engineering Fast ReRoute for link, node, and bandwidth protection. In: 2018 14th International Conference on Advanced Trends in Radioelecrtronics, Telecommunications and Computer Engineering (TCSET), pp. 1009-1013. IEEE (2018). https://doi.org/10.1109/TCSET.2018.8336365.

36. Lemeshko, O., Yeremenko, O., Yevdokymenko, M.: MPLS Traffic Engineering Solution of Multipath Fast ReRoute with Local and Bandwidth Protection In: Advances in Computer Science for Engineering and Education II. ICCSEEA 2019. Advances in Intelligent Systems and Computing, vol 938. Springer, pp. 113-125.

Рецензент: д-р техн. наук, проф. Д. В. Агеєв, Харківський національний університет радіоелектроніки, Харків Received (Надійшла) 10.06.2019

Accepted for publication (Прийнята до друку) 14.08.2019

\section{Математическая модель быстрой перемаршрутизации с балансировкой нагрузки и дифференцированного ограничения трафика в сети SD-WAN}

А. В. Лемешко, А. С. Шаповалова, А. С. Єременко, М. А. Евдокименко, А. М. Хайлан

В работе предложена математическая модель быстрой перемаршрутизации с обеспечением балансировки нагрузки на принципах Traffic Engineering (TE) и дифференцированного ограничения трафика в территориальнораспределенных программно-конфигурируемых сетях. Основу модели составляют условия реализации многопутевой маршрутизации совместно с модифицированными условиями сохранения потока, которые учитывают приоритетное ограничения трафика на границе сети в случае ее возможнй перегрузки, вызванной, с одной стороны, ростом нагрузки, а с другой - реализацией схем защиты элементов сети и ее пропускной способности в ходе быстрой перемаршрутизации. Преимуществом предлагаемого решения также является формулировка задачи быстрой перемаршрутизации как оптимизационной с критерием оптимальности, который ориентирован на минимизацию, вопервых, верхнего порога динамичного управления загруженностью каналов связи, который соответствует требованиям концепции TE, а, во-вторых, отказов в обслуживании на границе сети, взвешенных относительно приоритета и интенсивности потоков. Исследование процессов быстрой перемаршрутизации с использованием предложенной модели на ряде числовых примеров подтвердило адекватность и эффективность полученных на ее основе маршрутных решений как по обеспечению их отказоустойчивости и балансировки нагрузки, так и по основанному на приоритетах ограничениях трафика.

Ключевые слов а: SD-WAN, отказоустойчивость сетей, управление трафиком, балансировка нагрузки, быстрая перемаршрутизация, защита пропускной способности.

\section{Mathematical model of Fast ReRouting with load balancing and differentiated traffic policing in the SD-WAN network}

\section{O. Lemeshko, A. Shapovalova, O. Yeremenko, M. Yevdokymenko, A. Hailan}

The article is proposed a mathematical model of Fast ReRoute with load balancing based on Traffic Engineering principles and differentiated traffic policing in SD-WAN architectures. The use of the proposed model allows reducing the computational complexity of calculating routing variables responsible for the formation of the primary and backup paths. In addition, this model provides load balancing of network communication links in accordance with the requirements of the Traffic Engineering concept. The study of Fast ReRoute processes using the proposed model on a number of numerical examples confirmed the adequacy and effectiveness of routing solutions derived from it, both in terms of their resiliency, load balancing, and on priority-based traffic policing.

Keywords: SD-WAN, Network Resilience, Traffic Engineering, Fast ReRoute, Traffic Policing, Bandwidth Protection. 